\title{
The Translation of Parallelism in Arabic Political Speeches between Loss and Compensation: A Comparative Study
}

https://doi.org/10.33806/ijaes2000.22.1.2

\author{
Sana Fadi Shamaileh \\ Zayed University, UAE
}

Received on 29.6.2020 Accepted on 13.7.2021 Published on 1.1.2022

\begin{abstract}
Political discourse is characterized by stylistic and rhetorical features that distinguish it from other text genres. When a rhetorical feature such as parallelism is used frequently in Arabic political speeches, it becomes significant to highlight the fact that this recurrence of structure is deliberate. According to Islam \& Cahyani (2020: 273):

[T] he deliberate use of a word or phrase more than once in a sentence or a text to create a sense of pattern or form or to emphasize certain elements in the mind of the reader or listener [...] can be utilized [as] a major rhetorical strategy for producing emphasis, clarity, amplification, or emotional effect.

The objective of this study is to highlight the loss and the compensation of parallelism when translated from Arabic into English in political speeches at bottom-up level: word, sentence and chunk levels. This study shows that parallelism is used very frequently in Arabic political speeches and it is very popular among Arab political speakers as a rhetorical device to achieve persuasion, assertion and emotional effect on its audience.
\end{abstract}

Keywords: argumentative text type, compensation, parallelism, persuasion, political speeches, translation

\section{Introduction}

The initial motivation behind this study draws on the significant role parallelism plays as a rhetorical device in Arabic discourse in general and political speeches in particular. Parallelism occurs regularly in Arabic political speeches, which is due to its rhetorical and persuasive effects. It is through the repetition of structure that one can achieve emphasis, stress, cohesion and persuasion, and through phonological and morphological parallelism that one can create greater impact and persuasive force over his/her recipients.

Parallelism is an expression used to refer to repetition of syntactic structure or form in two or more configurations with new or different content. Parallelism is investigated by many scholars such as (De Beaugrande \& Dressler, 1981; Ivany, 1993; Jakobson, 1968; Johnstone, 1983; Petöfi, 1979), among others.

A parallel constituent is usually connected via junctive expressions. There are four major types of junctive expressions suggested by Petöfi (1979: 71) that are normally used to connect parallel constituents: conjunction which includes and, also, moreover, furthermore, in addition, besides, etc., disjunction which is achieved via the use of or, either/or, whether or not, etc., contra-junction that is manifested by but, however, yet, nevertheless, etc. and subordination which includes because, since, as, thus, while, therefore, etc. 
Junctives have a significant function when used in a text; they link the text and establish a relation between the connected sentences. Moreover, junctives can be used to "have control over how relations are recovered and set up by receivers" (Petöfi, 1979: 74). Accordingly, junctions operate as cohesive ties in parallelistic structures.

The following section will shed a light on the definition of parallelism by the above mentioned scholars, starting with de Beaugrande and Dressler (1981: 49) who describes it as "Repeating a structure by filling it with new elements" or "reusing surface formats but filling them with different expressions".

Another description of parallelism is provided by Ivany (1993) who states that:

The parallel line does not simply repeat what has been said, but enriches it, deepens it, transforms it by adding fresh nuances and bringing in new elements, renders it more concrete and vivid and telling- that is, it generates new (contextual) semantic reality from the lexical (word) meanings of its components. (pp. 49-50)

Furthermore, Johnstone (1991: 33) contends that "[t]o say that two linguistic structures are parallel is to say that they share a common structural frame, and that within this frame, some element or elements differ in form."

\section{Theoretical framework}

The field of translation studies has witnessed increased interest in the way rhetorical devices are used to underpin an argument in a stretch of text. Translating political speeches requires not only rendering the function and meaning of a speech but also maintaining, as much as possible, the stylistic and rhetorical devices in the TT in order to create the closest impact to that of the ST.

In this paper, the researcher will look at parallelism with reference to argumentative text type. Text typology is a vivid topic discussed by many scholars such as De Beaugrande and Dressler, 1981; Egon, 1976; Fowler, 2020; Hatim \& Baker 1998; Kress, 1985; among others. Most of political speeches fall under argumentative texts which are described by De Beaugrande \& Dressler (1981) as:

Texts to promote the acceptance or evaluation of certain beliefs or ideas as true vs. false, or positive vs. negative. Conceptual relations such as reason, significance volition, value and opposition should be frequent. The surface text will often show cohesive devices for emphasis and insistence, e.g., recurrence, parallelism and paraphrase. (p.184)

What distinguishes argumentative texts for Hatim \& Mason (2014: 159) is "the evaluation of relations between and among concepts through the extraction of similarities, contrast and transformations". Argumentation refers to the use of language "to justify or refute a standpoint, with the aim of securing agreement in views" (Van Eemeren et al., 2007: 208). Other discussions of argumentation are provided by Fisher, 2004; Jacobs, 1986; Perelman \& Olbrechts-Tyteca, 1969; among others. Text typology is built on the notion of function, i.e., a text is described by the function it fulfils. This paper will be looking at political 
argumentative texts, where the aim of political speeches is to persuade their recipients with the theme presented and have greater impact on them, while text receivers, in their turn, either accept or reject the argument. This is characterised by the function of argumentative texts which is described by Van Emeren et al. (1997) as:

Argumentation's function is to convince others of the truth, or acceptability, of what one says, the enduring questions addressed in the theory of argumentation have had to do with matters of evaluation: what it takes for a conclusion to be well supported, what criteria should govern acceptance of standpoint, and so on. (p. 210)

As argumentative texts aim at persuading the listener/reader with the speaker's/writer's point of view, parallelism is a key persuading device used frequently in Arabic argumentative discourse.

\section{Methodology and corpus of the study}

As parallelism is investigated from translation studies point of view, the discussion is going to illustrate through the use of a corpus of speeches delivered in Arabic by the Monarch of Jordan, King Abdullah the second, accompanied with their official English translations done by the Jordanian Royal Court. The comparison between the original example in Arabic and its English translated version is to highlight the achievement of parallelism in English translation, the frequency of occurrence of parallelism in both languages; how parallelism is dealt with in translation and the impact it creates to underpin an argument. The outcomes of this comparable analysis will enable the researcher to highlight the similarities and differences between the two languages in terms of their use of parallelism in the context of politics.

At the end of the analysis, the researcher will describe the frequency of occurrence of parallelism in a form of two tables. The first refers to the Arabic speeches and the second table refers to the English translations. The tables are used in order to highlight the extent to which the English translation has maintained a similar use of parallelism and has achieved a comparable impact on its recipients.

\section{Parallelism in political speeches}

\subsection{Function of parallelism}

Parallelism is not merely an aesthetic device. In contrast, it is a text building and structuring device as some texts and speeches are built and organised around this feature. Fitriyanti (2017: 425) states that "parallelism can be used as a source of producing sufficient talk. Repetition allows the speaker to set up a slot for additional information."

In general, when a syntactic duplication occurs in a speech, the intention behind that use is normally to add depth and solidity to it. Al-Shiyab (1999) stated the following:

The intensification of parallel recurrences aims at creating new material with equal importance and equal forcefulness [...] In other words, in 
repeating a word or a syntactic construction, the text-producer creates a marked and rhythmic effect, and arouses and reinforces emotions among readers as well as listeners. (p. 286)

Hence, the function of parallelism is manifested in intensifying and emphasizing a duplicated structure as well as drawing the attention of recipients to the parallel configuration which can leave greater emotional impact on them. Holes (2004) states that:

[Parallelism's] function is to add colour and detail, and provide the varying element which is necessary to allow the frame to be repeated again and again, emphasising its message. (p. 79)

In contrast, parallelism in English has a different function where it operates as a figure of speech rather than a text-structuring device: "The traditional Western notion [states] that parallelism is a figure of speech that is somehow added to an already-structured discourse" (Johnstone 1991: 32).

Another function of parallelism in Arabic political discourse is to operate as a cohesive tie; it can be argued that parallelism operates at lexical and semantic levels. At the lexical level, parallelism is achieved through the reiteration of the structure of lexical items, and at the semantic level the recurrence of a parallelistic structure builds up and strengthens its content, consequently, persuades the receiver. Arabic tends to use the particle (ان) (anna) to emphasise the whole argument. Repeating (أن) (?anna) in several parallelistic structure creates emphasis and cohesion among the reiterated structures. Consider the following example:

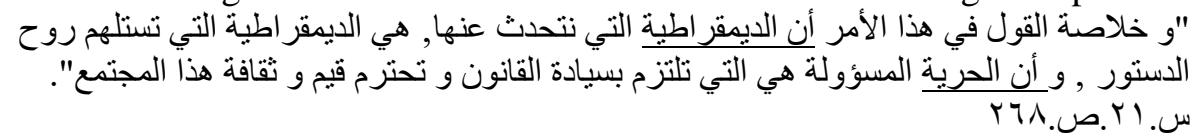

King Abdullah II, 2000, stated that "In short, the democracy we speak about is the democracy that stems from the constitution. Responsible freedom is the one that abides by the law, and respects the values and culture of this society" (p.317).

Reiterating parallelistic configurations in a speech creates an immediate emotional impact; this is attained through delivering well established and passionate argument with the aim of affecting and influencing the audience.

Some argumentative texts depend on textual features in order to achieve cohesion. When recurrence of a lexical item or pattern in a stretch of language is used intentionally by the producer of the text it functions as a cohesive tie. AlKufaishi (2006) claimed that:

Cohesion is a lexico-semantic relation encoded by lexical and lexicogrammatical forms. It is a lexical relation since it involves lexical items that enter into a network of intricate relationships with others and form a lexical set. It is semantic since it involves the persuasion and dependency relations. Lexical cohesion is realised through the presence of lexical chains that establish multi-connections among the lexical items and thus create textuality. (p. 10) 


\subsection{Types of parallelism}

That parallelism is repetition of structure or form draws one's attention to the degree and type of resemblance that is manifested in parallel structures. In other words, the degree of resemblance between parallel structures may vary between complete and partial correspondence. Furthermore, parallelism may include phonological and morphological repetition, among others.

A number of researchers have discussed the phenomenon parallelism with reference to Arabic in general and to Arabic prose in particular. The following researchers varied in their classifications to range from two to five types for parallelism. Koch (1983) divides parallelism into syntactic and semantic configuration. Moreover, Al-Shiyab (1990: 275) describes occurrence of cohesion in partial parallelism as "a mixture of lexical cohesion and syntactic cohesion". Similarly, Al-Jubouri (1984: 107-108) divides parallelism into two types according to their degree of competence: complete parallelism where there is total or almost complete correspondence between the parallelistic structures, and incomplete parallelism where partial correspondence occurs between the parallelistic forms. A further classification of parallelism discussed in Johnstone (1991: 29) includes phonological parallelism and morphological or syntactic parallelism. A substitution of the expression morphological parallelism with morphological echo and phonological parallelism with rhyme is presented by Holes (2004: 65-66), though he maintained the use of syntactic and semantic parallelism.

Many scholars have varied in their classification of the types of parallelism. Some of the classifications overlap; others have the same function but different naming as in Holes (2004) who substitutes morphological parallelism with morphological echo and phonological parallelism with rhyme. Another point worth mentioning is the variation in the number of classifications where they range between two to five types. Therefore, and for the purpose of this study, the researcher has come up with an evaluative classification that captures the relation between types of parallelism and suggests the following top-bottom description. The highest level of parallelism is repetition which is based not only on repeating the same structure, but also the same lexical item which is not our focus in this study. In order to narrow down the notion of parallelism, the researcher suggests two types: morphological and phonological parallelism. The former is identified with a) number, b) gender, c) definite article the, d) al-nisba-string, e) root repetition and f) cognate accusative, and the latter is manifested through a) rhyme, b) assonance, c) alliteration, and d) metrical foot which will be explained in details in the coming discussion.

The above suggested classification can be justified since repetition means repeating the same structure and content more than once which comes in a higher level than parallelism, which is based on repeating the same structure with new or different content. Moreover, morphological parallelism means repeating the same structure (i.e. morphological derivation) but with a different content which makes it type of parallelism. As for phonological parallelism, it is based on repeating the same structure with the same rhyme or phonological resemblance but with 
different content which considers it as another type of parallelism.

The fact that the above mentioned types of parallelism have one thing in common which is repeating the same structure puts them under an overarching category which is syntactic parallelism which includes: repetition of the same structure, word order and number of words.

Table 1: Classification of types of parallelism

\begin{tabular}{|c|c|}
\hline \multicolumn{2}{|c|}{$\begin{array}{l}\text { Repetition } \\
\text { an overarching category for parallelism }\end{array}$} \\
\hline \multicolumn{2}{|c|}{$\begin{array}{l}\text { Parallelism } \\
\text { which is repetition of the same structure/ form and includes: }\end{array}$} \\
\hline 1. Morphological parallelism & 2. Phonological parallelism \\
\hline
\end{tabular}

\subsubsection{Morphological parallelism}

It can be argued that morphological parallelism in Arabic language can be created by gender, number, definite article (the), al-nisba string, root repetition and cognate accusative. Morphological parallelism which is created by gender is categorised into either masculine or feminine. In Arabic the feminine is marked by the overt morpheme (¿), whereas the masculine has no such mark. Consider the following example:

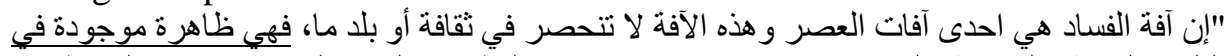

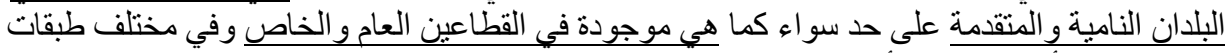

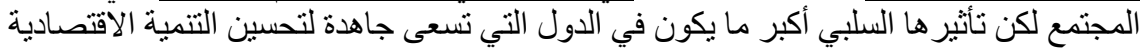

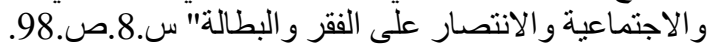

King Abdullah II, 2005 claimed that "Corruption is one of the plagues of our age; it is not specific to a certain culture or country; rather, it is a phenomenon found in developing and developed countries alike, in public and private sectors of society. But its negative effects are greatest in those countries that strive to improve economies and social development and conquer poverty and unemployment" (p.98).

Parallelism in this example occurs at the word level through the use of the feminine indicator (') in النامية و المتقدمة (developed and developing). However, parallelism in الخاص و العام (public and private) is achieved through the use of the same verbal noun in a masculine form without an indicator. Moreover, a semantic relation occurs here, where the lexical items النامية و المتقدمة are synonymous and the pair الخاص و العام have a contrastive relation.

Morphological parallelism is also manifested via number. This can be achieved through three classifications found in Arabic: singular, dual (آن) and plural (ات، ون) or broken plural. English, on the other hand, has singular and plural 
forms(s).

The definite article (the), which is a prefix added to the beginning of a noun or an adjective, is another marker of morphological parallelism. It is used in Arabic more frequently than in English, where a series of English nouns can be defined by one use of the definite article (the). For instance, consider the following example:

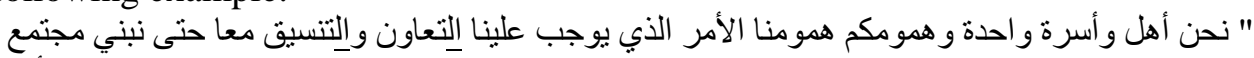

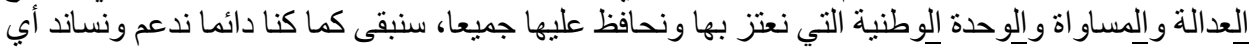

$$
\begin{aligned}
& \text { حق لكم و أبي حق لأهلناو إخو اننا غرب النهر حتى يقيمو ا دولتهم المستقلة على نر ابهم الوطني" س. } \\
& \text { ص. } 09
\end{aligned}
$$

King Abdullah II, 2000 stated that "We are all one family, and your concerns are ours. Therefore, we must co-operate and co-ordinate together in order to build a society that is based on justice, equality and national unity of which we are proud, and which we shall always protect and maintain. As always, we will remain supportive of your right, and the rights of our brothers in the West Bank to establish their independent state on their national soil" (p.67).

Here, parallelism occurs with the lexical items (العدالةو المساواةو الوحدة الوطنية) where the four items start with the definite article (the) and end with the feminine marker (o). Moreover, parallelism occurs in (التنسيق والتعاون) as they start with the article (al-). As for the English translation, it does not include any morphological parallelism, neither in the use of the feminine marker (i) at the end of the lexical items nor in the use of the definite article (the).

Not all morphological patterns in Arabic are morphologically parallel in English. Nisba-string, root repetition and cognate accusative are specific to Arabic, which is an issue discussed by Johnstone (1991: 58-59). For instance, the morphological pattern (أوائل، أواخر) is morphologically parallel where both lexical items are broken plural; they are non-countable nouns and they have alliteration where the initial of the two lexical items is the same. English, on the other hand, uses the pairs (early and late), where they are monosyllabic and are not morphologically parallel. Johnstone (1991: 58-59) argues that:

The distinction between an acceptable pairing and an unacceptable one is not as great in English as it is in Arabic, and while the members of each English pair are structurally similar [...] they are not parallel in the way the Arabic pairs are, and in fact could not be, given the morphological system of English.

Another example refers to the use of al- nisbah string (the addition of the morpheme -iyya/ -iyyatun for the feminine and -iyyun for the masculine to create an adjectival connection). The nisbah suffix is a morphological repetition that creates phonological patterning in terms of using the same rhyme. Consider the following example:

$$
\text { "إني نذرت نفسي لخدة الشعب الأردني الوفي، العربي الوجه و الضمير و الرسالة و الذي أعنز بالانتماء }
$$

King Abdullah II, 1999 stated that "I have pledged myself to serve the loyal

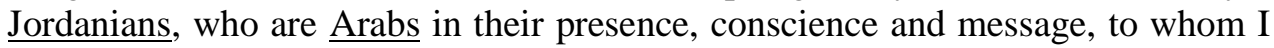
cherish belonging" (p. 109). 
In the above example, it can be noticed that morphological parallelism which occurs through the repetition of al-nisbah string -iyy, which is added to the end of the three lexical items (أردني، وفي، عربي). The English translation, on the other hand, could not retain this structure as this feature is language specific; hence, parallelism and rhyme are not maintained.

A further example that manifests language constraint is root repetition, where it is a common style in Arabic language. Consider the following example:

$$
\begin{aligned}
& \text { "إن اعتز ازي بمجلسكم الكريم هذا، اعتزاز بلا حدود، فهو رمز لإِرادة الثعب الأردني الحرة، و هو معقل }
\end{aligned}
$$

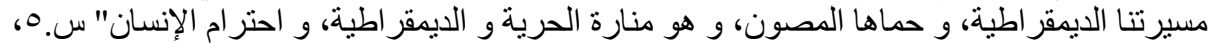

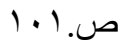

King Abdullah II, 1999 stated that "My esteem for your honourable Assembly is unlimited. Your Assembly is symbol of the free Jordanian will and it is the stronghold and fortress of our democratic path. It is the beacon of freedom, democracy and respect for human rights" (p.109).

It is quite noticeable from this example that root repetition was manifested in Arabic language (اعتزاز); however, it was not attained in the English language.

\subsubsection{Phonological parallelism}

Phonological parallelism is created by repetition of the same sound in two or more constituents; this can be attained at through the use of (القافية) Al-Qa:fiyah (Rhyme), (السجع) Al-Sajac (Assonance) which is described by Hussein (2001: 139) as "the repetition of the same sounds at word final position", (الجناس الاستهالالي) Aljina:s Al-istihla:ly (Alliteration) which refers to "the repetition of the same initial letter, whether a consonant or a vowel in successive words within a sentence or phrase" Hussein (2001: 138), and finally (الوزن الصرفي) Al-wazin Al-Sarfy (Metrical foot) which is related to lexical items "which are rhythmically exactly parallel" (Beeston, 1974: 137). Consider the following example which illustrates Al-jina:s Al-istihla:ly (Alliteration):

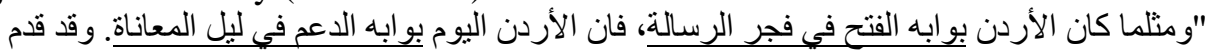

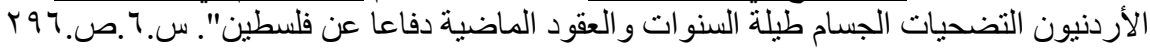

According to King Abdullah II, 2000, “Similar to Jordan's role as a gateway for opening up to the world, Jordan today is the gateway of support in the suffering darkness of night. Jordanians sacrificed substantially in the past years and decades, in defense of Palestine" (p.356).

In this example, phonological parallelism is manifested through the use of

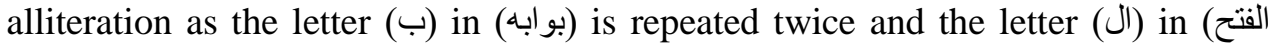
(الرسالة المعاناة، is repeated four times. Moreover, the words (المعاناة، الرسالة، الدعم، (بو ابه) end with the same sound (') and create rhyme. Finally, the metrical foot of the first noun phrase (بوابة الفتح في فجر الرسالة) is similar to the metrical foot of the

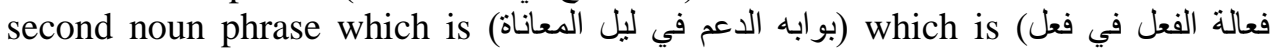
(المفاعلة

Another example on phonological parallelism highlights Al-Sajac (Assonance). Consider the following example:

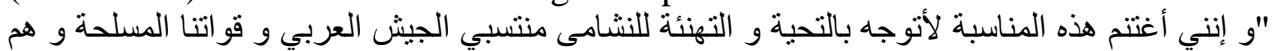

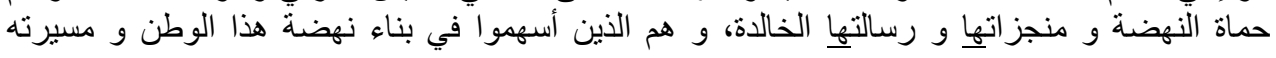




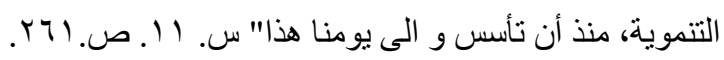

King Abdullah II, 2000 claimed that "I seize this occasion to salute and congratulate the brave Arab Army conscripts, the guards of the renaissance, of its accomplishments and eternal message, those who contributed to this nation's renaissance and its developmental course since the day of the Army's establishment and up to the present" (p. 309).

In the above example, assonance is manifested in the Arabic language through repetition of the same sound at the end of the words (منجزاتهاو رسالتها), whereas it was lost in the English translation, as the words (accomplishments, message) do not rhyme.

\subsection{Levels of parallelism}

The researcher's choice of the levels of parallelism investigated in this paper has been dictated by what has been data-driven to some extent. The researcher has found that parallelism occurs at three levels, first of which is the lexical level where two or more lexical items have the same structure (i.e., syntactic, morphological, phonological or semantic resemblance). Second, parallelism can also be achieved at sentence level; Arabic grammarians look at a sentence by classifying it into nominal and verbal sentences (Abu Al-Su'wd, 2002). Third, which is the most generic level of parallelism found in the corpus of study, is the chunk level, where parallelism stretches over two or more paragraphs. The term chunk was found to be adopted by a number of writers such as Al-Jubouri 1984; De Beaugrande and Dressler 1981; Johnstone 1991; among others. According to Al-Jubouri, (1984), "The word 'chunk' is a convenient expression here, and it is used to refer to phrases, clauses and larger discourse sequences" (p. 107). Accordingly, the investigation of parallelism in Arabic and English will be undertaken at lexical, sentence and chunk levels.

\subsubsection{Parallelism at lexical level}

Arabic political speeches are characterised and distinguished by a heavy use of the verbal embellishment السجع Al-Sajac (Assonance) at word level. Assonance can be described as two lexical items or more ending with the same letter(s) rhyme.

Another verbal embellishment used in Arabic is الجناس الاستهلالي Al-jina:s Alistihla:ly (Alliteration) which occurs at word level and consists of repeating the initials of two lexical items or more. Parallelism at word level is very common and is used frequently in Arabic based on the grammatical configurations of Arabic such as: accusative case, personal pronoun, masculine plural, dualism, feminine marker and alliteration. Consider the following example:

"و في هذا الصدد فإنني أتطلع الى إنجاز قانون انتخابي عصري يتيح للجميع فرصة المنافسة الحرة الثريفة

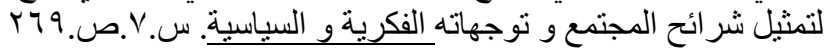

King Abdullah II, 2000 claimed that "In this respect, I look out for the formulation of a modern election law that gives everyone the opportunity to free and fair competition, to present the various sectors of society with its various political and cultural colors" (p.318).

In the Arabic sentence, parallelism is achieved between the lexical items 
(الحرة و الثريفة) (free and fair) where the two items create morphological parallelism via the use of the feminine marker ( $\dot{0})$ which incorporates rhyme and creates phonological parallelism and by the use of the definite article (the) which creates alliteration at the phonological level. Another instance of parallelism occurs between the lexical items (الفكرية و السياسية) (political, cultural) where both the lexical items are adjectives that manifest morphological parallelism by the definite article (ال) and the feminine marker ( $)$ ( ).

As for phonological parallelism, this is achieved through rhyme manifested at the end of the lexical items, alliteration using the same initials and metrical foot according to the pattern (الفعلية). As for the English translation, parallelism was not achieved between the lexical items (free, fair), whereas it was maintained in the second couplet via the use of the adjectives (political, cultural) which have rhyme in their endings (-al) though they do not have alliteration as they do not use the definite article as was the case in Arabic. The use of parallelism creates emphasis and draws the recipients' attention to the parallel constituent, which is achieved in the ST but not in the English translation.

$$
\begin{aligned}
& \text { "فالأردنيون أمام القانون سواء و العدل أساس الحكم و هو الضمانة للحفاظ على قيم التسامح و الترابطو }
\end{aligned}
$$

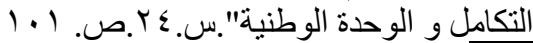

King Abdullah II, 1999 stated that "Jordanians are equal by law. Justice is the base of governing and guarantor of the values of tolerance, affinity, integration and national unity" (p.110).

A distinguishing feature of political discourse refers to the use of a series of elements, in this example three elements were used in order to achieve emphasis and a persuasive effect over the audience (التسامح ، الترابطو التكامل). This effect is further strengthened by the use of phonological parallelism, which is created by alliteration in (الت), and the use of the same metrical foot according to the pattern (التفاعل), in addition to morphological parallelism manifested in the definite article (ال) . The English translation is able to maintain the use of three elements achieves emphasis and attracts recipients' attention to the listed elements, though morphological and phonological parallelisms are not retained.

\subsubsection{Parallelism at sentence level}

As mentioned earlier, Arabic is known for its use of both nominal and verbal sentences. Looking into these types, الجملة الإسمية (a nominal sentence) can be described as a sentence that begins with a noun and occurs at the beginning or middle of a paragraph, whereas الجملة الفعلية (a verbal sentence) refers to a sentence that starts with a verb followed by a subject and in most cases a complement.

The following example will reflect the manifestation of parallelism in a nominal sentence followed by an example on a verbal sentence.

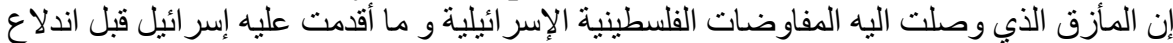

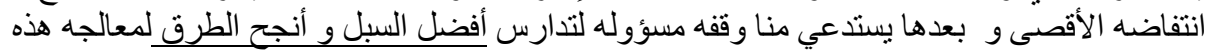

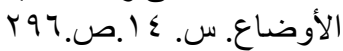

King Abdullah II, 2000 suggested that "The impasse the Palestinian Israeli negotiations have reached, and the actions Israel undertook before the eruption of the Aksa Intifada and after it, demand our taking a responsible halt, to 
contemplate the best ways and useful means to deal with this situation" (p. 35702).

This is an example that reflects collocation in a parallel constituent. Parallelism is achieved through a repetition of the grammatical structure of an adjective in the superlative degre (أفضل وأنجح) (the best, useful) and manifest phonological parallelism via alliteration in (i) and sharing the same metrical foot according to the pattern (أفعل) , followed by a noun (السبل والطرق) (ways and means) which have morphological parallelism via the article (ال) and a semantic relation of synonymy that occurs between the two lexical items. Furthermore, the lexical items (أفضل السبل) and (أنجح الطرق) collocate and the use of collocational sets strengthens an argument. As for the English translation, it maintained the superlative degree of the first lexical item (the best); however, this was not the case with the second lexical item (useful). As for the second lexical items (السبل (ways and means) they were translated successfully in the English version and the semantic relation was maintained.

\subsubsection{Parallelism at chunk level}

Parallelism at chunk level occurs at a larger scale than the levels of lexical items and sentences as it stretches over more than one paragraph. Consider the following example:

$$
\begin{aligned}
& \text { حضرات الأعيان، }
\end{aligned}
$$

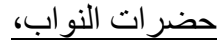

$$
\begin{aligned}
& \text { لقد كانت مسيرتنا الديمقر اطية و ستظل خيارنا الوطني الذي لا رجئ رجعة عنه ومجلسكم الكريم هذا عنو انها }
\end{aligned}
$$

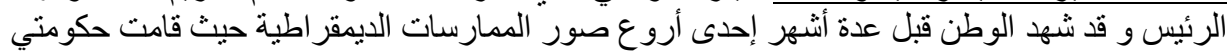

$$
\begin{aligned}
& \text { بإجر اء الانتخابات للمجالس البلدية } \\
& \text { بمنته بالنز اهة و الحياد و الدقة و التنظيم وستعمل حكومتي على ترسيخ قو اعد هذه المسيرة الديمقر اطية و فتح }
\end{aligned}
$$

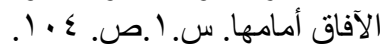

King Abdullah II, 1999 said:

"Honourable Senators,

Honourable Deputies,

Our democratic course has been and will remain our unwavering national course. Your honourable Assembly is its central feature. The country witnessed a few months ago one of its best democratic experiences when my government ran municipal council elections with utmost integrity, impartiality, efficiency, and organisation. My government will firmly carry on strengthening this democratic course and opening new horizons" (p. 113).

$$
\begin{aligned}
& \text { حضر ات الأعيان، } \\
& \text { حضرات النواب، الأبان، } \\
& \text { لقد كان الأردن وسيظل بعون الله وارث رسالة الثورة العربية الكبرى وأهدافها وغاياتها النبيلة في الحرية }
\end{aligned}
$$

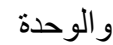

$$
\begin{aligned}
& \text { و الحياة الأفضل وسيظل كما كان على الدوام عربي الانتماء و الموقف والرسالة.و إنطلاقا من هذه الرؤية الرونية }
\end{aligned}
$$

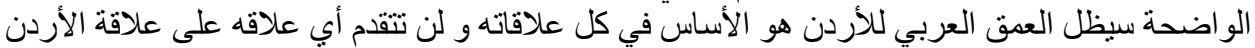

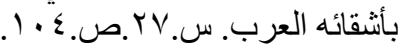

King Abdullah II, 1999 said: 
"Honourable Senators,

Honourable Deputies,

Jordan has been and will always remain, God willing, the inheritor of the message of the Great Arab Revolt and its noble aims and aspirations in freedom, unity and better life. Jordan will always be loyal to its Arab roots. Its relations with other Arab states will only stem from these roots. No relation with any country will take precedence over Jordan's relations with its Arab brethren” (p. 114).

It can be noticed from the above example that parallelism stretches over two separate paragraphs. The formula of address (حضرات الأعيان/ حضرات النواب) (honourable senators/ honourable deputies) which are repeated in two paragraphs are constituted of the same structure, i.e. a noun that ends with a feminine plural $(ا ت)$ + a noun with an article (ال) . This structure which achieves morphological and phonological parallelism via the use of the definite article (the), feminine plural $(ا ت)$ and rhyme in $(ا ت)$ is successfully retained in the English translation through the use of an adjective ending with the suffix (-able),

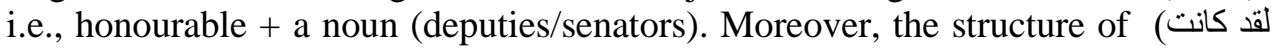
(مسيرتنا الديمقراطية وستظل) (our democratic course has been and will remain) is parallel to ( لقد كان الأردن وسيظل بعون اللهن (Jordan has been and will always remain) which share almost the same structure.

In this example, the English translation was able to maintain parallelism at the chunk level and to connect the speech by formulas of address.

Following the above analysis of the corpus of the study and the investigation of parallelism levels, a description in a form of two tables is provided firstly to highlight the frequency of occurrence of parallelism at the described levels, i.e., word, sentence and chunk levels; secondly, to draw a comparison of its frequency of occurrence in Arabic and in English. Table (2) A shows the number of parallel configurations found in the Arabic speeches, whereas table (2) B presents the number identified in the translated version.

The approach used in describing parallelism is based on the degree of correspondence which is classified by the researcher into: parallel, when there is total or almost total correspondence between parallelistic configurations, semiparallel or incomplete parallelism when there is partial correspondence between parallel forms and zero parallelism is used to refer to incidents where parallelism is not achieved in the English translation. The criterion of this description is the degree of correspondence between the original speeches and its translation.

Table 2: (A) Frequency of occurrence of parallelism in Arabic political speeches

\begin{tabular}{|c|c|c|c|}
\hline \multicolumn{4}{|c|}{ Frequency of occurrence of parallelism in Arabic political speeches } \\
\hline Word Level & \multicolumn{2}{|c|}{ Sentence Level } & Chunk Level \\
\hline & $\begin{array}{c}\text { Nominal } \\
\text { Sentence }\end{array}$ & $\begin{array}{c}\text { Verbal } \\
\text { Sentence }\end{array}$ \\
\hline 5 & 1 & 1 & 1 \\
\hline
\end{tabular}


Table 2: (B) Frequency of occurrence of parallelism in the English translation

\begin{tabular}{|c|c|c|c|c|c|c|c|c|c|c|c|}
\hline \multicolumn{10}{|c|}{ Srequency of occurrence of parallelism in the English translation } \\
\hline \multicolumn{2}{|c|}{ Word Level } & \multicolumn{7}{c|}{ Chunk Level } \\
\hline $\begin{array}{c}\text { Par } \\
\text { a }\end{array}$ & $\begin{array}{c}\text { Sem } \\
\text { i }\end{array}$ & $\begin{array}{c}\text { Zer } \\
\text { o }\end{array}$ & $\begin{array}{c}\text { Par } \\
\text { a }\end{array}$ & $\begin{array}{c}\text { Sem } \\
\text { i }\end{array}$ & $\begin{array}{c}\text { Zer } \\
\text { o }\end{array}$ & $\begin{array}{c}\text { Par } \\
\text { a }\end{array}$ & $\begin{array}{c}\text { Sem } \\
\text { i }\end{array}$ & $\begin{array}{c}\text { Zer } \\
\text { o }\end{array}$ & $\begin{array}{c}\text { Par } \\
\text { a }\end{array}$ & $\begin{array}{c}\text { Sem } \\
\text { i }\end{array}$ & $\begin{array}{c}\text { Zer } \\
\text { o }\end{array}$ \\
\hline 1 & 2 & 2 & - & 1 & - & - & - & 1 & 1 & - & - \\
\hline
\end{tabular}

Table (2) A shows that five instances of parallelism were found at word level in the original Arabic speeches, whereas in the translated version only one instance maintained parallelism, two were semi parallel and two instances did not maintain parallelism. Moving on to parallelism at the sentence level, one instance of parallelism was found in nominal sentences and another instance in verbal sentences. However, in the English translation one instance of semi-parallelism was achieved at nominal sentences, whereas zero parallelism was manifested at the verbal sentences.

As for parallelism at chunk level, one instance was manifested in the Arabic speech and one instance of parallelism was achieved in the English translation.

Overall, eight instances of parallelism were used in Arabic at the above mentioned levels; the English translation, on the other hand, retained two instances of parallelism, three of semi-parallelism, and finally three instances where the translation could not maintain the parallel structure.

\section{Conclusion}

To conclude, there are two types of parallelism: morphological and phonological and in many instances of parallelism, semantic relations are manifested. As shown from the corpus, parallelism plays an axis role in Arabic discourse in general and political speeches in particular where it is "the heart of the [Arabic] language [...] which cannot simply be disposed of" (Johnstone, 1991: 119). Different types of parallelism can be manifested at lexical, sentence or chunk levels. It can be noticed from the corpus of study that Arabic political discourse is an accommodating environment for parallelism at all its levels. Based on the analysis carried out in this article, it can be suggested that in some cases it is the formal restrictions of English language that have made it difficult for the translator to compensate parallelism at word, sentence and chunk levels. There is no reason to assume that every language favours the same amount of redundancy or uses the same mixture of means to maintain cohesion. It would seem that Arabic tends to favour lexical repetition while English prefers ellipsis (Williams, 
1984: 125). Further studies are recommended to examine the use of parallelism in speeches delivered originally in English to be used as a reference for the investigation of the English translations.

Sana Fadi Shamaileh

Zayed University, UAE

ORCID Number: 000-0002-1658-1917

Email: sana.shamaileh@zu.ac.ae

\section{References}

Abu Al-Su'wd, S. (2002). The simplified syntax. (Vol.1). Alexandria: Dar Al Wafa.

Al-Jubouri, A. (1984). 'The role of repetition in Arabic argumentative discourse'. English for specific purposes in the Arab world, 99-117.

Al-Kufaishi, A. (2006). 'Lexical cohesion patterns in Arabic and English expository texts'. Poznan Studies in Contemporary Linguistics Journal, 42, 7-33.

Al-Shiyab, S. (1990). The structure of argumentation in Arabic editorial as a case study. Unpublished $\mathrm{PhD}$ thesis, Herriot-Watt University, Edinburgh.

Beeston, A. F. (1974). 'Parallelism in Arabic prose'. Journal of Arabic Literature, 5, 134-146.

De Beaugrande, R. A., \& Dressler, W. U. (1981). Introduction to text linguistics (Vol. 1). London: Longman.

Egon, W. (1976). A text grammar of English. Heidelberg: Quelle and Meyer.

Fisher, A. (2004). The logic of real arguments. Cambridge, Uk: Cambridge University Press.

Fitriyanti, M. (2017). 'A Stylistic analysis of verbal parallelism in Michelle Obama's speech at Hillary for America Campaign in New Hampshire'. Sastra Inggris - Quill,6: 417-430.

Fowler, R. (2020). 'Linguistic criticism'. In The Language and Literature Reader (pp. 49-59). London: Routledge.

Hatim, B., \& Mason, I. (2014). Discourse and the translator. London: Routledge.

Hatim, Basil and Mona Baker. (1998). 'Discourse analysis and translation'. In Routledge Encyclopedia of Translation Studies. 67-71. London: Routledge. 
Holes, C. (2004). Modern Arabic: Structures, functions, and varieties. Washington, D.C.: Georgetown University Press.

Hussein, A. R. (2001). Arabic stylistics: A coursebook. Wiesbaden: Harrassowitz Verlag.

Islam, A. F., \& Cahyani, D. A. (2020). 'A Stylistic analysis of persuasion wonderful Indonesia's advertisement'.Jo-ELT (Journal of English Language Teaching), 3(2): 70-78.

Ivany, T. (1993). 'Dynamic vs. static- a kind of parallelism in Al-Hamadani's Maqamat'. Colloquium on Arabic lexicography and lexicography, 49-58. Budapest: Hungary.

Jacobs, S. (1986). 'How to make an argument from example in discourse analysis'. Contemporary issues in language and discourse processes, 149167. Hillsdale, NJ: Lawrence Erlbaum.

Jakobson, R. (1968). 'Poetry of grammar and grammar of poetry'. Lingua, 21, 597-609.

Johnstone, B. (1991). Repetition in Arabic discourse: Paradigms, syntagms, and the ecology of language (Vol. 18). John Benjamins Publishing.

King Abdullah II. (1999, November 1). Speech from the Throne By His Majesty King Abdullah II Opening the Third Ordinary Session of the 13th Parliament. The Hashemite Royal Court: Jordan.

King Abdullah II. (2000, June 19). Letter of high commission to the government of His Excellency Mr. Ali Abu Ragheb. The Hashemite Royal Court: Jordan.

King Abdullah II. (2005, June 26). Message of His Majesty King Abdullah II to Prime Minister Adnan Badran on the establishment of a commission to implement a general anti-corruption strategy. Kingabdullah.jo.

Koch, B. J. (1983). 'Presentation as proof: The language of Arabic rhetoric'. Anthropological linguistics, 25(1), 47-60.

Kress, G. (1985). Ideological structures in discourse. Handbook of discourse analysis, 4(1), 22-42.

Perelman, C., \& Olbrechts-Tyteca, L. (1969). The new rhetoric: A treatise on argumentation. 19, 411-412. University of Notre Dame Press.

Petöfi, J. S. (1979). Text vs sentence: Basic questions of text linguistics. Hamburg: Buske.

Van Eemeren, F. H., Houtlosser, P., \& Henkemans, A. S. (2007). Argumentative indicators in discourse: A pragma-dialectical study (Vol. 12). Dordrecht, The Netherlands: Springer Science \& Business Media. 
Williams, M. (1984). 'A problem of cohesion'. In John Swales and Mustafa Hasan (Eds.), English for specific purposes in the Arab world. 118-128. Birmingham: University of Aston. 